\title{
PENERAPAN MODEL PEMBELAJARAN TERPADU TIPE NESTED DALAM PEMBELAJARAN PEMECAHAN MASALAH MATEMATIKA PADA MATERI INDUKSI MATEMATIKA
}

\author{
Aan Armini \\ SMAN 1 Garawangi Kabupaten Kuningan, Jalan Raya Garawangi No. 34, Kuningan, \\ Jawa Barat, Indonesia \\ aanarmini123@gmail.com
}

\begin{abstract}
Through classroom action research, researchers seek to improve students 'mathematical problem solving abilities on mathematical induction material by using nested integrated learning methods and explore students' attitudes towards the application of the given learning model. The study was conducted during two cycles which included four stages of learning, namely: planning, implementation, observation, and reflection. The study was conducted in the odd semester of the 2019/2020 school year involving 34 students of class XI MIPA-2 SMAN 1 Garawangi, Kuningan. There are 2 types of research instruments used, namely tests and questionnaires. Based on the test results, it can be seen that in the post-test, the N-Gain index obtained was 0.61 (moderate). Meanwhile, based on the results of the questionnaire, it can be seen that $100 \%$ of students show a positive attitude. Thus, it can be concluded that the nested type integrated learning model can improve students' mathematical problem solving abilities on mathematical induction material and get a good appreciation with the presence of a positive attitude shown by all participants.

Keywords: mathematical induction, mathematical problem solving, Nested integrated learning model
\end{abstract}

Abstrak
Melalui penelitian tindakan kelas, peneliti berupaya meningkatkan kemampuan pemecahan masalah
matematika siswa pada materi induksi matematika menggunakan metode pembelajaran terpadu tipe
nested serta menggali sikap siswa terhadap penerapan model pembelajaran yang diberikan. Penelitian
dilaksanakan selama dua siklus yang mencakup empat tahapan pembelajaran, yaitu: perencanaan,
pelaksanaan, observasi, dan refleksi. Penelitian dilaksanakan pada semester ganjil tahun ajaran
2019/2020 dengan melibatkan 34 siswa kelas XI MIPA-2 SMAN 1 Garawangi Kabupaten Kuningan.
Terdapat 2 jenis instrumen penelitian yang dipakai, yaitu tes dan angket. Berdasarkan hasil tes, dapat
diketahui bahwa pada post-test, indeks N-Gain yang diperoleh adalah 0,61 (sedang). Sementara itu,
berdasarkan hasil angket, dapat diketahui bahwa 100\% siswa menunjukkan sikap positif. Dengan
demikian, dapat disimpulkan bahwa model pembelajaran terpadu tipe nested mampu meningkatkan
kemampuan pemecahan masalah matematika siswa pada materi induksi matematika serta
mendapatkan apresisai yang baik dengan adanya sikap positif yang ditunjukkan oleh seluruh
partisipan.
Kata Kunci : Induksi matematika, pemecahan masalah matematika, model pembelajaran terpadu
tipe nested

Cara Menulis Sitasi: Armini, A. (2020). Penerapan Model Pembelajaran Terpadu Tipe Nested dalam Pembelajaran Pemecahan Masalah Matematika pada Materi Induksi Matematika. Jurnal Edukasi dan Sains Matematika (JES-MAT),6 (2), 113-128. 


\section{PENDAHULUAN}

Dengan adanya teori bilangan, aljabar, analisis, teori peluang, matematika diskrit serta lainnya, matematika menjadi salah satu bidang ilmu dasar yang esensial dalam pengembangan ilmu pengetahuan dan teknologi. Selain itu, matematika mempunyai peran yang penting dalam berbagai disiplin ilmu dan memajukan daya pikir manusia (Depdiknas, 2008). Berdasarkan hal tersebut, matematika menjadi mata pelajaran yang diberikan dari mulai jenjang pendidikan dasar. Hal ini berdasarkan anggapan bahwa matematika membekali peserta didik dengan kemampuan berpikir logis, analitis, sistematis, kritis, kreatif dan kemampuan bekerjasama sehingga siswa dapat beradaptasi secara kompetitif dalam pengembangan ilmu pengetahuan dan teknologi. Hal ini sejalan dengan tujuan yang diharapkan dalam pembelajaran matematika oleh National Council of Teachers of Mathematics / NCTM (2000), yang menetapkan lima standar kemampuan matematis yang harus dimiliki oleh peserta didik, yaitu kemampuan pemecahan masalah, komunikasi, kemampuan koneksi, penalaran, dan representasi.

Namun demikian, masih terdapat asumsi bahwa matematika hanya sekedar berhitung atau bermain dengan angkaangka. Sehingga pada prakteknya, siswa hanya belajar teori atau konsep matematika, sehingga siswa akan merasakan kesulitan dalam memecahkan masalah matematika. Hal ini sejalan dengan pernyataan Trianto (2007) bahwa ketika pembelajaran yang diberikan hanya berupa pemberian konsep, maka pembelajaran tersebut tidak akan bermanfaat bagi siswa. Tidak hanya itu, sulitnya siswa dalam memahami materi yang diajarkan, menjadikan matematika sebagai pelajaran yang kurang disenangi. Terlebih lagi, ketika guru tidak mampu menyederhanakan materi pembelajaran untuk dipahami siswa di kelas ataupun ketika siswa pasif dalam pembelajaran, maka hal tersebut membuat matematika semakin rumit untuk dipelajari. Hal ini didukung oleh Yuanari (2011) bahwa rendahnya kemampuan pemecahan masalah siswa dikarenakan masih banyaknya siswa yang kurang aktif dalam pembelajaran matematika di kelas maupun dalam mengerjakan soal matematika.

Masalah lainnya dalam pembelajaran matematika dikemukakan oleh Ekawati (2010) yang menyatakan bahwa peserta didik hanya menghapal konsep dan kurang mampu menentukan masalah serta merumuskan masalah matematika tersebut, sehingga mereka mengalami kesulitan dalam mengunakan konsep tersebut jika menemui masalah dalam kehidupan nyata. Pada dasarnya, pemahaman konsep tidak bisa diartikan hanya mengingat saja atau mengikuti prosedur dalam penyelesaian soal, tetapi perlu pembuktian, membedakan mana yang contoh atau yang bukan contoh, menggeneralisasikan, menganalogikan, mengaplikasikan, dan merepresentasikan konsep (Idris, 2009). Tak dapat dipungkiri bahwa kemampuan siswa dalam memahami konsep matematika serta dalam memecahkan masalah matematika tentunya akan mempengaruhi hasil pembelajaran di kelas. Akan tetapi pada prakteknya, siswa terbiasa mengerjakan soal-soal rutin yang membuat siswa tidak dapat memecahkan suatu masalah apabila diberikan soal-soal bentuk non-rutin (Anggraini, Rusdy, \& Ilma, 2010). Dengan kata lain, siswa terbiasa memecahkan masalah matematika melalui cara yang diberikan oleh guru, sehingga siswa cenderung memecahkan 
masalah dengan konsep yang diberikan oleh guru saja.

Selain itu, Juanti, Santoso \& Hiltrimartin (2016) mengemukakan bahwa dalam pelaksanaan tes pemecahan masalah matematika, hanya 33\% siswa yang mampu mengerjakan soal matematika dengan baik dan benar. Sehingga dapat dikatakan bahwa, kemampuan matematika peserta didik masih perlu ditingkatkan lagi. Kemampuan matematika siswa tidak hanya merujuk pada perhitungan dasar, tetapi juga bagaimana menggunakannya untuk menganalisis masalah yang kompleks dan memperkirakan efisiensi cara yang berbeda dari pemecahan masalah yang ada dalam kehidupan (Cai \& Steven, 2005). Dengan kata lain, siswa harus terbiasa untuk menganalisis beragam masalah yang kompleks sehingga kemampuan matematika siswa dalam memecahkan masalah matematika dapat mengalami peningkatan.

Kemampuan pemecahan masalah merupakan kemampuan yang sangat penting dalam pembelajaran matematika (Aini, 2016). Untuk mengatasi hal tersebut, diperlukan suatu model pembelajaran matematika yang tidak hanya menekankan kepada pengetahuan suatu konsep saja, melainkan model pembelajaran yang mampu merangsang daya pikir siswa untuk membentuk pengetahuan mereka sendiri dalam memecahkan beragam masalah matematika. Sejatinya, tidak ada satupun model pembelajaran yang dianggap lebih baik dibandingkan dengan model pembelajaran yang lain. Baik tidaknya suatu model pembelajaran bisa dilihat dari efektif atau tidaknya model tersebut digunakan untuk mencapai tujuan pembelajaran yang telah ditentukan. Pemilihan model pembelajaran harus disesuaikan dengan materi ajar dan tujuan dari pembelajaran, sehingga dapat memperjelas konsep-konsep yang diberikan, sehingga hasilnya peserta didik akan selalu berpikir dan berperan aktif. Dengan adanya tujuan belajar proses pembelajaran akan lebih terarah sehingga tidak akan keluar atau menyimpang dari materi ajar.

Beberapa peneliti terdahulu telah melakukan penelitian untuk meningkatkan kemampuan pemecahan masalah diantaranya, Aini (2016) melakukan upaya peningkatan pemecahan masalah melalui pembelajaran open-ended. Akhyar \& Rokhmah (2018), melakukan upaya peningkatan kemampuan pemecahan masalah matematis siswa melalui model pembelajaran Knisley berbasis masalah. Firdaus (2019) melalukan upaya peningkatan pemecahan masalah melalui pembelajaran probing promting. Fathani, Ilmi, dan Santriyo (2020) melakukan penelitian mengenai penerapan group investigation untuk meningkatkan kemampuan pemecahan masalah kontekstual dalam pembelajaran pertidaksamaan rasional dan irrasional. Berdasarkan beberapa penelitian terdahulu, yang berupaya meningkatkan kemampuan pemecahan masalah, para peneliti tersebut menggunakan model pembelajaran inovatif sebagai upaya untuk meningkatkan kemampuan pemecahan masalah matematis siswa. Dengan banyaknya model pembelajaran matematika yang telah diterapkan, dalam penelitian ini, penulis bermaksud untuk memperkaya sumber literatur pembelajaraan matematika dengan menerapkan salah satu metode pembelajaran terpadu.

Model pembelajaran terpadu merupakan pendekatan pembelajaran yang 
memungkinkan siswa secara individual maupun kelompok aktif mencari, menggali, dan menemukan konsep serta prinsip secara holistik dan otentik. Melalui model pembelajaran terpadu siswa dapat menemukan sendiri hal-hal yang berkaitan dengan materi pembelajaran sehingga siswa terlatih untuk menemukan sendiri konsep yang dipelajari secara holistik, bermakna dan otentik. Dalam model pembelajaran terpadu terdapat berbagai macam tipe pembelajaran, dimana salah satunya yaitu model pembelajaran terpadu tipe nested. Kurniawan (2014) mengatakan bahwa Model pembelajaran terpadu tipe nested adalah pembauran dari banyak target kemampuan yang ingin dicapai disajikan dalam satu topik yang ada pada satu mata pelajaran tertentu yang difokuskan dengan kemampuan sosial, kemampuan berpikir, dan kemampuan penguasaan.

Model pembelajaran terpadu tipe nested dalam pembelajaran matematika secara khusus memadukan keterampilan berfikir dan keterampilan mengorganisir siswa. Melalui kegiatan ini, siswa diharapkan dapat mengklasifikasikan suatu materi dan mengorganisir materi agar siswa dapat mengembangkan kemampuan yang dimiliki dalam menyelesaikan soal-soal yang membutuhkan pemahaman yang tinggi. Salah satu hal yang dapat dilakukan siswa dalam pembelajaran pemecahan masalah matematika ialah dengan penalaran. Penalaran pada matematika dapat menggunakan prinsip induksi matematika (Huda, Isnarto, \& Erwina, 2018). Dengan demikian, dalam penelitian ini, penulis menerapkan salah satu metode pembelajaran terpadu tipe nested dalam pemecahan masalah matematika pada materi induksi matematika.
Terdapat beberapa penelitian yang menerapkan metode pembelajaran terpadu tipe nested. Pertama ialah penelitian Sari (2019) yang telah menerapkan pembelajaran terpadu tipe nested pada pembelajaran tematik di tingkat sekolah dasar. Dimana hasil penelitiannya menyatakan bahwa treatment yang diterapkan memiliki pengaruh yang signifikan terhadap hasil belajar siswa.

Penelitian kedua ialah penelitian Ekawati (2010) yang menerapkan pembelajaran terpadu model nested terhadap kemampuan pemecahan masalah matematika. Hasil penelitian menunjukan adanya peningkatan dalam pembelajaran di kelas eksperimen yang menunjukan bahwa siswa dapat menyelesaikan masalah matematika maupun masalah kehidupan sehari-hari yang berkaitan dengan konsepkonsep dalam materi fungsi dengan menggunakan berbagai macam keterampilan dan prosedur matematika, menyusun langkah-langkah, merumuskan pola dan strategi khusus dalam menyelesaikan masalah berdasarkan indikator pemecahan masalah. Selain itu, kemampuan pemecahan masalah matematis siswa yang diajarkan dengan pembelajaran terpadu tipe nested lebih tinggi dibandingkan dengan pembelajaran konvensional. Penelitian Ekawati (2010) menunjukan bahwa penggunaan pembelajaran model terpadu tipe nested memberikan pengaruh yang signifikan terhadap kemampuan pemecahan masalah matematika siswa.

Berdasarkan paparan latar belakang tersebut, peneliti tertarik untuk melakukan penelitian untuk meningkatkan kemampuan pemecahan masalah matematika siswa pada materi induksi matematika dengan menggunakan metode pembelajaran 
terpadu tipe nested dan menggali sikap siswa terhadap penerapan metode pembelajaran terpadu tipe nested.

\section{LANDASAN/KAJIAN TEORI Induksi Matematika}

Induksi matematika merupakan metode pembuktian yang dapat digunakan untuk menentukan kebenaran dari suatu pernyataan yang diberikan dalam bentuk bilangan asli (Kristanto, 2013). Induksi matematika dapat digunakan untuk: (a) membuktikan bahwa teori atau sifat itu benar untuk semua bilangan asli atau semua bilangan dalam himpunan bagiannya, (b) pembuktian pernyataan, (c) mengecek hasil proses yang terjadi secara berulang dengan pola tertentu, (d) membuktikan universal statement, dsb. Dalam pengerjaannya, terdapat tiga tahapan induksi matematika, yaitu langkah dasar (basis step), langkah induktif (inductive step), dan Kesimpulan (conclusion).

\section{Pemecahan Masalah Matematika}

Pemecahan masalah matematika ialah penggunaan matematika baik itu untuk matematika itu sendiri ataupun aplikasi matematika di kehidupan sehari-hari dan ilmu pengetahuan yang lain secara kreatif untuk menyelesaikan masalah-masalah yang belum diketahui cara penyelesaiannya (Hudoyo dalam Suwangsih, 2006). Dalam pembelajaran matematika, suatu masalah dapat dikatakan masalah matematika karena mengandung konsep matematika didalamnya. Masalah tersebut bisa disajikan dalam bentuk soal tidak rutin yang berupa soal cerita, penggambaran fenomena atau kejadian, ilustrasi gambar dan teka-teki. Sejalan dengan Hudoyo (Suwangsih, 2006) yang mengelompokkan masalah matematika kedalam 4 jenis, yaitu: a) masalah transalasi, masalah kehidupan sehari-hari yang memerlukan transalasi dari bentuk verbal ke bentuk matematika;

b) masalah aplikasi, memberikan kesempata siswa untuk menyelesaikan masalah dengan menggunakan berbagai macam keterampilan dan prosedur matematika;

c) masalah proses, memberikan kesempatan siswa untuk menyusun langkah-langkah merumuskan pola dan strategi khusus dalam menyelesaikan masalah;

d) masalah teka-teki, merangsang keterampilan afektif siswa dalam pembelajaran.

Pemecahan masalah matematika tidak terlepas dari pengetahuan seseorang akan substansi penyelesaian masalah tersebut, sehingga hal ini merupakan suatu kemampuan yang harus dimiliki oleh setiap siswa. Pemecahan masalah merupakan tahapan berbeda pada pembelajaran soal matematika karena memerlukan berbagai pengetahuan konsep matematika. Sejalan dengan Suwangsih (2006) bahwa dalam pemecahan masalah diperlukan proses berfikir tingkat tinggi dan mempunyai peranan yang penting dalam pembelaja matematika. Terdapat 4 langkah penyelesaian pemecahan masalah matematika yang diusulkan oleh Polya (Suwangsih, 2006), yaitu pemahaman masalah, membuat rencana penyelesaian, mengerjakan rencana, dan peninjauan kembali hasil perhitungan. Dengan demikian, dapat dikatakan bahwa dalam pemecahan masalah membutuhkan pengetahuan matematika siswa yang tinggi serta beragam proses didalamnya guna menghasilkan jawaban atas masalah matematika tersebut. 


\section{Pembelajaran Terpadu}

Istilah pembelajaran terpadu berasal dari kata "integrated teaching and learning" atau "integrated curriculum approach”. Konsep ini dikemukakan oleh Jhon Deway sebagai usaha untuk mengintegrasikan perkembangan dan pertumbuhan siswa dan kemampuan pengetahuannya (dalam Maharani, Wahidin \& Ria, 2015). Pembelajaran terpadu merupakan pendekatan yang mengintegrasikan beberapa mata pelajaran yang berkaitan secara harmonis untuk memberikan pengalaman belajar yang bermakna kepada siswa (Ananda \& Abdillah, 2018). Hal ini sejalan dengan Jacobs (Maharani, 2015) yang memandang pembelajaran terpadu sebagai pendekatan kurikulum terindisipliner (interdisiplnary curriculum approach) yang mengaitkan dan memadukan materi ajar dalam suatu mata pelajaran, antar mata pelajaran dengan semua aspek perkembangan anak, kebutuhan dan minat anak, serta kebutuhan dan tuntutan lingkungan sosial keluarga. Dengan demikian dapat disimpulkan, pembelajaran terpadu adalah suatu pembelajaran yang mengaitkan beberapa aspek, baik dalam intra pelajaran maupun antar mata pelajaran sehingga siswa dapat memperoleh pengetahuan dan keterampilan secara utuh sehingga pembelajaran mejadi lebih bermakna.

Pembelajaran terpadu memiliki satu tema aktual, dekat dengan dunia siswa, dan ada kaitannya dengan dunia sehari-hari. Tema ini menjadi alat pemersatu materi yang seragam dari beberapa materi pembelajaran yang mungkin saling terkait. Materi-materi yang dipilih dapat mengungkapkan tema secara bermakna. Hal ini sejalan dengan Sumantri (2016) yang menyatakan bahwa pembelajaran terpadu memiliki beberapa karakteristik tersendiri, diantaranya berpusat pada peserta didik, autentik, pemisahan antar bidang studi tidak begitu jelas, menyajikan konsep dari berbagai bidang studi dalam suatu proses pembelajaran, luwes, serta hasil pembelajaran dapat berkembang sesuai dengan minat dan kebutuhan peserta didik. Dengan demikian salah satu kunci pembelajaran terpadu adalah menyediakan lingkungan belajar dimana siswa terlibat dalam memahami semua disiplin ilmu secara bermakna dalam suatu pembelajaran.

Terdapat beberapa tipe pembelajaran terpadu yang dapat digunakan pendidik dalam melaksanakan pembelajaran. Ditinjau dari cara memadukan konsep, keterampilan, topik, dan unit tematisnya, terdapat sepuluh tipe dalam merencanakan pembelajaran terpadu, yaitu (1) fragmented, (2) connected, (3) nested, (4) sequenced, (5) shared, (6) webbed, (7) threaded, (8) integrated, (9) immersed, dan (10) networked (Fogarty dalam Trianto, 2017). Berdasarkan beberapa tipe pembelajaran terpadu diatas, tipe pembelajaran terpadu yang dipilih adalah pembelajaran terpadu tipe nested (tersarang).

\section{Model Pembelajaran Terpadu Tipe Nested}

Pembelajaran terpadu tipe nested merupakan suatu pembelajaran yang memfokuskan pada pengintegrasian beberapa keterampilan belajar yang ingin dikembangkan oleh seorang pendidik kepada peserta didiknya dalam suatu proses pembelajaran untuk tercapainya materi pelajaran (Fogarty dalam Trianto, 2017). Hal ini sejalan dengan Dimyati (2016) bahwa tipe nested merupakan perpaduan 
dari berbagai bentuk penguasaan konsep keterampilan melalui sebuah kegiatan pembelajaran.

Berdasarkan pendapat ahli diatas, dapat disimpulkan bahwa pembelajaran terpadu tipe nested adalah suatu bentuk pengintegrasian keterampilan-keterampilan belajar dalam suatu unit pembelajaran untuk ketercapaian materi pelajaran. Untuk jenis mata pelajaran sosial dan bahasa dapat dipadukan keterampilan berpikir dengan keterampilan sosial, sedangkan untuk mata pelajaran sains dan matematika dapat dipadukan keterampilan berfikir dan keterampilan mengorganisir (Fogarty dalam Trianto, 2017). Dengan demikian, dalam pelaksanaanya, penelitian ini menerapkan keterampilan berfikir dan keterampilan mengorganisir.

Tabel 1. Unsur-unsur keterampilan berfikir, keterampilan sosial, dan keterampilan mengorganisir

\begin{tabular}{lll}
\hline & \multicolumn{2}{c}{ Keterampilan } \\
\hline \multicolumn{1}{c}{ Berfikir } & \multicolumn{1}{c}{ Sosial } & \multicolumn{1}{c}{ Mengorganisir } \\
Prediction & Attentive listening & Web \\
Inference & Clarifying & Venn diagram \\
Hypothesize & Paraphrasing & Flow chart \\
Compare/contrast & Encouraging & Cause-effec circle \\
Classify & Accepting ideas & Agree/disagree chart \\
Generalize & Disagreeing & Grid/matrix \\
Prioritize & Consensus seeking & Concept map \\
Evaluate & Summarizing & Fishbone \\
\hline
\end{tabular}

Proses pembelajaran nested dilakukan melalui tahapan-tahapan agar mempermudah pendidik melaksanakan pembelajaran dikelas. Menurut Trianto (2017) dalam merancang pembelajaran terpadu tipe nested setidaknya ada tiga tahap yang harus diperhatikan, yaitu:

a) Tahap Perencanaan

- Menentukan jenis mata pelajaran, jenis keterampilan yang dipadukan.

- Memilih kajian materi, SK, KD dan indikator.

- Menentukan sub keterampilan yang dipadukan.

- Merumuskan tujuan pembelajaran khusus (indikator).

- Menentukan langkah-langkah pembelajaran. b) Tahap Pelaksanaan

- Pendidik hendaknya tidak menjadi single actor yang mendominasi kegiatan pembelajaran.

- Pemberian tanggung jawab baik secara individu maupun kelompok harus jelas dalam setiap tugas yang menuntut adanya kerja sama kelompok.

- Pendidik perlu akomodatif terhadap ide-ide yang terkadang sama sekali tidak terpikirkan dalam proses perencanaan.

c) Tahap Evaluasi

- Memberi kesempatan kepada peserta didik untuk melakukan evaluasi diri di samping bentuk evaluasi lainnya

- Pendidik perlu mengajak peserta didik untuk mengevaluasi perolehan belajar 
yang telah dicapai berdasarkan kriteria keberhasilan pencapaian tujuan yang dicapai.

Guna merancang alur pembelajaran sesuai dengan proses yang telah ditetapkan, penulis akan menerapkan tahapan pembelajaran pemecahan masalah matematika dengan menggunakan model pembelajaran tipe nested sesuai dengan rancangan pembelajaran yang telah disusun oleh Ekawati (2010), yang mencakup:

1. Orientasi Peserta Didik Terhadap Masalah

Dimulai dengan peserta didik di bagi menjadi beberapa kelompok untuk menumbuhkan kesadaran akan masalah yang harus di pecahkan.

2. Merumuskan Masalah

Rumusan masalah berhubungan dengan kejelasan dan kesamaan persepsi tentang masalah dan berkaitan dengan datadata yang harus dikumpulkan.Diharapkan peserta didik dapat menentukan prioritas masalah.

3. Merumuskan Hipotesis

Peserta didik diharapkan dapat menentukan sebab akibat dari masalah yang ingin diselesaikan dan dapat menentukan berbagai kemungkinan penyelesaian masalah.

4. Mengumpulkan Data

Peserta didik didorong untuk mengumpulkan data yang relevan.Kemampuan yang diharapkan adalah peserta didik dapat mengumpulkan data dan memetakan serta menyajikan dalam berbagai tampilan yang sudah dipahami. Dengan cara memadukan keterampilan keterampilan yang dimilikinya untuk menyelesaikan masalah yang dihadapi.

5. Mempresentasikan Hasil
Peserta didik mempresentasikan hasil diskusi dari data yang sudah dikumpulkan, melalui interaksi peserta didik diajak membahas permasalahan yang disajikan.

6. Refleksi

Peserta didik menyimpulkan hasil pembelajaran.

\section{METODE PENELITIAN \\ Jenis Penelitian}

Penelitian ini menggunakan penelitian tindakan kelas dengan tujuan meningkatkan kemampuan pemecahan masalah matematis siswa pada materi induksi matematika menggunakan model pembelajaran terpadu tipe nested serta mengeksplor sikap siswa terhadap penerapan model pembelajaran tersebut. Penelitian ini terdiri dari dua siklus, tiap siklus ada empat tahapan, yaitu: perencanaan, pelaksanaan, observasi, dan refleksi.

\section{Waktu dan Tempat Penelitian}

Penelitian dilaksanakan pada semester ganjil tahun ajaran 2019/2020 bertempat di SMAN 1 Garawangi Kabupaten Kuningan.

\section{Subjek Penelitian}

Objek penelitian merupakan siswa kelas XI MIPA-2 yang berjumlah 34 orang siswa.

\section{Prosedur}

Peneliti berperan sebagai pengajar serta melibatkan satu pengajar matematika lainnya sebagai kolaborator. Selanjutnya, hal yang pertama dilakukan ialah pre-test yang bertujuan untuk mengukur tingkat kemampuan siswa sebelum treatment diberikan. Kemudian, hasil pre-test dijadikan dasar pengembangan rancangan pembelajaran pada siklus pertama dengan menggunakan model pembelajaran terpadu 
terpadu tipe nested pada materi pembelajaran induksi matematika sebagai tahapan perencanaan. Kemudian, peneliti yang berperan sebagai pengajar menerapkan rancangan pembelajaran tersebut.

Sementara itu, kolaborator melaksanakan perannya sebagai observer pada tahapan observasi. Setelah pelaksanaan pembelajaran berakhir selanjutnya peneliti memberikan latihan soal guna mengukur tingkat keberhasilan pembelajaran, yang selanjutnya nilai siswa serta hasil observasi dibahas dalam tahapan refleksi. Hasil dari tahapan refleksi menjadi bahan acuan dalam pembuatan rancangan pembelajaran pada siklus kedua penelitian. Siklus kedua berjalan sesuai dengan tahapan pada siklus pertama. Setelah siklus kedua berakhir, peneliti kemudian melakukan post-test guna menguji tingkat keberhasilan pembelajaran. Sebagai tahap akir penelitian, peneliti selanjutnya menyebarkan angket kepada siswa guna mengeksplor sikap siswa terhadap pembelajaran.

\section{Data, Intrumen, dan Teknik Pengumpulan Data}

Berdasarkan tujuan penelitian, peneliti menggunakan 2 jenis instrumen penelitian, yaitu tes dan angket. Test merupakan instrumen yang digunakan untuk mengidentifikasi efek penerapan model pembelajaran terpadu tipe nested terhadap kemampuan pemecahan masalah matematika siswa pada materi induksi matematika. Dalam penelitian ini, tes dilakukan selama dua kali, yaitu pre- test dan post- test. Pre-test dilaksanakan sebelum pembelajaran dilakukan, sementara post-test dilakukan setelah siklus kedua selesai dilaksanakan.
Selanjutnya, instrumen yang kedua ialah angket yang digunakan untuk mengeksplor sikap siswa terhadap penerapan model pembelajaran terpadu tipe nested dalam pengajaran pemecahan masalah matematika pada materi induksi matematika. Penulis menggunakan closedended questionnaires sebagai instrument. Dalam angket yang diberikan kepada responden terdapat 20 pertanyaan yang mana responden harus mengisi alternatif jawaban yang tertera dalam angket dengan 5 pilihan jawaban. Pendistribusian angket dilaksanakan setelah post-test dilaksanakan.

\section{Teknik Analisis Data}

Tes dianalisis dengan mengggunakan Uji N-Gain. Rumus indeks gain yang digunakan adalah sebagai berikut:

$$
\text { Indeks gain }=\frac{\text { nilai posttest }- \text { nilai pretest }}{\text { nilai maks }- \text { nilai pretest }}
$$

Kriteria nilai $\mathrm{N}-\mathrm{Gain}$ sebagai berikut :

$$
\begin{array}{ll}
\mathrm{N} \text {-gain }>0,70 & =\text { tinggi } \\
0,30<\mathrm{N} \text {-gain }<0,70 & =\text { sedang } \\
\mathrm{N} \text {-gain }<0,30 & =\text { rendah }
\end{array}
$$

Sementara itu, angket menggunakan lima poin Likert Scale. Skala yang dipakai ialah Sangat Setuju (5), Setuju (4), Raguragu (3), Tidak Setuju (2), dan Sangat Tidak Setuju (1). Skor akan dikalkulasikan dengan mengggunakan Microsoft office excels agar menghindari kesalahan dalam penghitungannya.

Presentase skor angket yaitu :

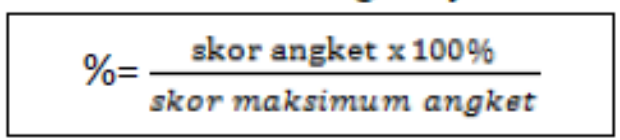

Skor setiap kuesioner dianalisa berdasarkan lima tingkatan sikap siswa, yaitu sangat positif, positif, normal, negatif, dan sangat negatif. Tingkatan ini ditampilkan dalam Tabel 2. 
Tabel 1 Interpretasi Tingkatan Sikap Siswa

\begin{tabular}{cc}
\hline Tingkatan sikap siswa & Skor \\
\hline Sangat Negatif & $0 \%-20 \%$ \\
\hline Negatif & $21 \%-40 \%$ \\
\hline Normal & $41 \%-60 \%$ \\
\hline Positif & $61 \%-80 \%$ \\
\hline Sangat Positif & $81 \%-100 \%$ \\
\hline
\end{tabular}

(Riduan, 2009)

\section{HASIL PENELITIAN DAN \\ PEMBAHASAN \\ Penerapan model pembelajaran terpadu tipe nested dalam pengajaran pemecahan masalah matematika pada materi induksi matematika}

Bagian ini memaparkan hasil dan pembahasan temuan penelitian berkaitan dengan penerapan model pembelajaran terpadu tipe nested dalam pengajaran pemecahan masalah matematika pada materi induksi matematika. Hasil dan pembahasan terbagi kedalam dua bagian, sesuai dengan tujuan penelitian.

1. Efek Penerapan Model Pembelajaran Terpadu Tipe Nested dalam

\section{Pengajaran Pemecahan Masalah Matematika pada Materi Induksi Matematika \\ Penerapan model pembelajaran} terpadu tipe nested dalam pengajaran pemecahan masalah matematika pada materi induksi matematika dilaksanakan selama 2 siklus dimana tiap siklus ada empat tahapan, yaitu: perencanaan, pelaksanaan, observasi, dan refleksi. Guna mengetahui efek penerapan treatment tersebut, peneliti menggunakan instrumen tes. Terdapat empat kali tes yang dilakukan, yaitu pre-test, tes pada siklus 1 , tes pada siklus 2, serta post-test. Nilai pada masingmasing tes ditampilkan pada Gambar 1 .

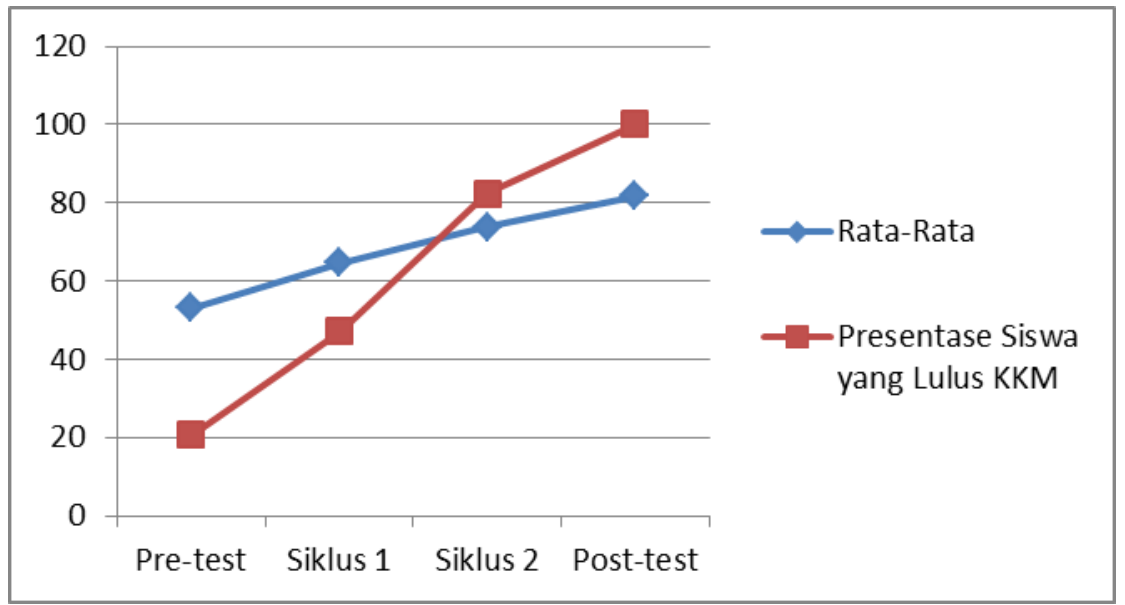

Gambar 1. Nilai Tes Siswa

Berdasarkan gambar 1, dapat yang lulus KKM yang ditetapkan sebesar diketahui bahwa nilai rata-rata siswa pada pre-test adalah 53,15, dengan jumlah siswa 65 adalah 7 orang siswa $(20,6 \%)$. Hal ini tentunya menjadi dasar bagi peneliti untuk 
meningkatkan kemampuan pemecahan masalah matematika siswa pada materi induksi matematika melalui model pembelajaran terpadu tipe nested.

Sementara itu, pada siklus 1, dapat diketahui bahwa nilai rata-rata siswa pada siklus 1 adalah 64,65, dengan jumlah siswa yang lulus KKM adalah 16 orang siswa $(47,06 \%)$. Sehingga dapat diketahui indeks $\mathrm{N}$-Gain siklus 1 adalah 0,25. Dengan nilai indeks tersebut, maka dapat diketahui bahwa kriteria nilai n-gain pada siklus 1 masih rendah $(\mathbf{0 , 2 5}<0,30)$. Dengan demikian, diperlukan siklus selanjutnya untuk mencapai indeks yang lebih besar.

Selanjutnya, berdasarkan Diagram 1, dapat diketahui bahwa nilai rata-rata siswa pada siklus 2 adalah 73,76, dengan jumlah siswa yang lulus KKM adalah 28 orang siswa $(82,35 \%)$. Dengan demikian dapat diketahui bahwa indeks $\mathrm{N}$-Gain siklus 2 adalah 0,44 , dimana nilai n-gain pada siklus 2 termasuk kedalam kriteria sedang $(0,30<\mathbf{0 , 4 4}<0,70)$. Dengan adanya peningkatan nilai rata-rata siswa, jumlah siswa yang lulus KKM serta peningkatan indeks N-Gain, maka tidak diperlukan adanya siklus tambahan pada pembelajaran pemecahan masalah matematika pada materi induksi matematika melalui model pembelajaran terpadu tipe nested.

Kemudian, pada post-test, dapat diketahui bahwa nilai rata-rata siswa pada post-test adalah 81,82, dengan jumlah siswa yang lulus KKM adalah 34 orang siswa (100\%), dengan indeks N-Gain sebesar 0,61 (sedang). Dengan demikian, dapat disimpulkan bahwa model pembelajaran terpadu tipe nested mampu meningkatkan kemampuan pemecahan masalah matematika siswa pada materi induksi matematika yang dibuktikan dengan adanya peningkatan pada nilai ratarata siswa, jumlah siswa yang lulus KKM serta peningkatan indeks N-Gain (kriteria sedang).

Hasil penelitian ini sejalan dengan Ekawati (2010) yang menyimpulkan bahwa setelah belajar dengan menggunakan model pembelajaran terpadu tipe nested, kemampuan pemecahan masalah matematika siswa lebih baik dibandingkan dengan siswa yang belajar dengan menggunakan metode ajar konvennsional. Dimana nilai rata-rata siswa kelas eksperimen lebih tinggi dibandingkan dengan nilai rata-rata siswa kelas kontrol.

\section{Sikap Siswa Terhadap Penerapan Model Pembelajaran Terpadu Tipe Nested dalam Pengajaran Pemecahan Masalah Matematika pada Materi Induksi Matematika}

Berikut data tingkatan sikap siswa terhadap penerapan model pembelajaran terpadu tipe nested dalam pembelajaran pemecahan masalah matematika pada materi induksi matematika 


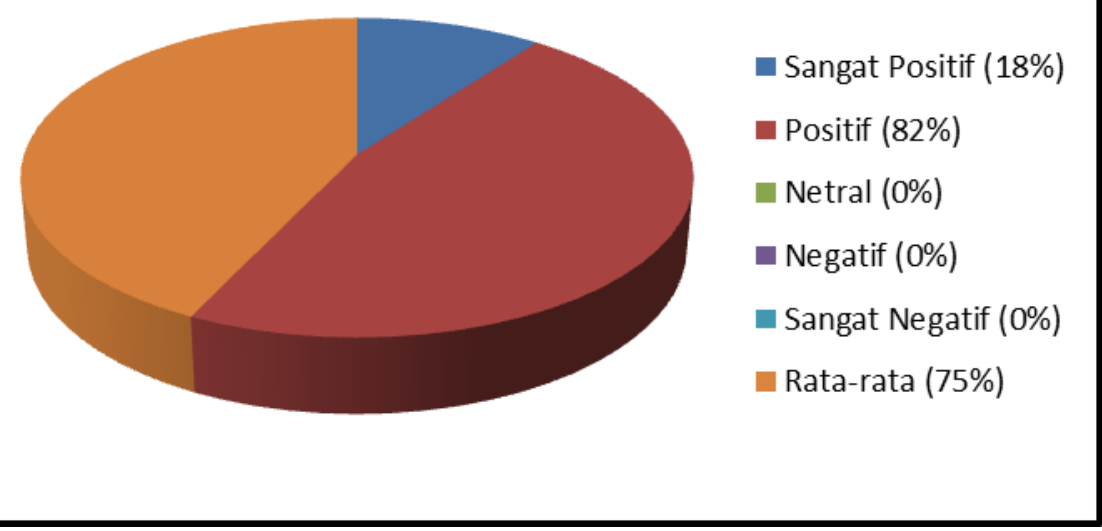

Gambar 2. Tingkatan Sikap Siswa Terhadap Penerapan Model Pembelajaran Terpadu Tipe Nested dalam Pengajaran Pemecahan Masalah Matematika pada Materi Induksi Matematika

Gambar 2 menampilkan tingkatan sikap siswa terhadap penerapan model pembelajaran terpadu tipe nested dalam pengajaran pemecahan masalah matematika pada materi induksi matematika yang didapat dari penyebaran angket kepada 34 siswa. Berdasarkan Diagram 2 dapat diketahui bahwa $18 \%$ siswa memberikan sikap sangat positif terhadap penerapan model tersebut serta $82 \%$ diantaranya memberikan sikap positif. Sementara itu, terdapat $0 \%$ siswa yang memberikan sikap netral maupun negatif terhadap penerapan model tersebut. Selain itu, hasil rata-rata yang didapat ialah $75 \%$. Dengan kata lain, dapat disimpulkan bahwa $100 \%$ siswa menyikapi pembelajaran pemecahan masalah matematika pada materi induksi matematika menggunakan model pembelajaran terpadu tipe nested dengan sikap yang positif.

Dari hasil angket yang diberikan kepada siswa yang menyatakan bahwa siswa memberikan sikap positif terhadap penerapan model pembelajaran terpadu tipe nested dalam pengajaran pemecahan masalah matematika pada materi induksi matematika menjadi bukti bahwa metode ini layak untuk diterapkan dalam pembelajaran. Dengan menggunakan metode ini, siswa dapat menambah wawasan dalam pembelajaran induksi matemtika melalui diskusi kelompok dan presentasi. Melalui hal tersebut, siswa dapat saling bertukar ide sehingga hasil pembahasan menjadi lebih mendalam. Selain itu, siswa juga dapat mengetahui dan mempelajari cara pemecahan masalah matematika dengan beragam cara melalui hasil diskusi. Dalam metode ini, siswa berlatih beragam masalah matematika berkatian dengan induksi matematika, sehingga siswa dapat memecahkan masalah matematika dengan cara yang bervariatif. Selain itu, melalui penerapan metode ini, ketertarikan, semangat dan antusias siswa meningkat. Hal ini tercermin dari proses pembelajaran yang dilaksanakan, dimana siswa lebih semangat dalam mengerjakan tugas yang diberikan oleh guru. Hal ini tentunya berpengaruh terhadap hasil tes yang ada, dimana adanya peningkatan kemampuan pemecahan masalah matematika siswa, sesuai dengan hasil penelitian pertama. Dengan demikian, hal tersebut mengindikasikan bahwa dengan adanya sikap positif siswa terhadap pembelajaran terpadu tipe nested dapat 
membantu siswa meningkatkan kemampuan pemecahan masalah matematika. Hasil ini sejalan dengan pernyataan Darsono (2012) dalam penelitiannya bahwa respon siswa terhadap pembelajaran terpadu yang tergolong sangat kuat. Selain itu, hal ini pun didukung oleh Kusuma, Wahidin, \& Gloria (2015) yang menyatakan bahwa secara umum siswa merespon positif penggunaan metode pembelajaran terpadu tipe nested (tersarang) terhadap kemampuan literasi sains siswa dalam pembelajaran biologi.

\section{SIMPULAN DAN SARAN}

\section{Simpulan}

Berdasarkan hasil tes dan angket yang diberikan kepada siswa terhadap penerapan model pembelajaran terpadu tipe nested selama 2 siklus, dapat diketahui bahwa model tersebut mampu meningkatkan kemampuan pemecahan masalah matematika siswa pada materi induksi matematika. Hal ini didukung dengan hasil post-test dimana $100 \%$ siswa mencapai nilai KKM yang ditetapkan sebesar 65 dengan nilai rata-rata yang diperoleh pada post-test adalah sebesar 81,82 serta kriteria nilai N-Gain sebedar 0,61 (sedang). Selain itu, hasil angket pun menyatakan bahwa $100 \%$ siswa memberikan sikap positif terhadap penerapan model pembelajaran terpadu tipe nested.

\section{Saran}

Berdasarkan Hasil penelitian yang telah di paparkan, peneliti mengajak para pengajar matematika untuk menerapkan model pembelajaran terpadu tipe nested untuk diterapkan di kelas. Selain itu, peneliti pun mengajak peneliti yang lain untuk mengembangkan hasil penelitian ini, dengan cara menerapkan model pembelajaran terpadu tipe nested pada bidang pembelajaran yang lain.

\section{DAFTAR PUSTAKA}

Ananda \& Abdillah. (2018). Pembelajaran Terpadu (Karakteristik, Landasan, Fungsi, Prinsip dan Model). Medan: LPPPI.

Aini, I., N. (2016). Upaya meningkatkan kemampuan pemecahan masalah matematika siswa melalui pendekatan open-ended. Jurnal Edukasi dan Sains Matematika (JES-MAT), 2(2), pp. $29-40$

Akhyar, M.,K. \& Rokhmah, M. (2018). Efekivitas Model Pembelajaran Knisley Berbasis Masalah Terhadap Kemampuan Pemecahan Masalah Matematis Pada Pokok Bahasan PLDV. Jurnal Edukasi dan Sains Matematika (JES-MAT), 4(2), pp. 141-152

Anggraini, L., Rusdy, S., A., \& Ilma, R. (2010). Penerapan Model Pembelajaran Investigasi Kelompok Untuk Meningkatkan Kemampuan Pemecahan Masalah Matematika Siswa Kelas Viii-4 Smp Negeri 27 Palembang. Jurnal Pendidikan Matematika, 4(1)

Cai, J., \& Steven, H. (2005). Generalized and Generative Thinking in U.S and Chinese Students' Mthematical Problem Solving and Problem Posing. Journal of mathematical Behavior, 2(1), pp. 401-21

Darsono. (2012). Pengaruh Penerapan Metode Percobaan Ipa Terpadu Terhadap Keterampilan Proses Sains Dan Hasil Belajar IPA Siswa Kelas VIII Di SMPN 1 Kalasan Dengan Tema "Makanan" [diakses di 
http://eprints.uny.ac.id/9166/1/\%20$\% 2008312241001 . p d f]$

Departemen Pendidikan Nasional. (2008). Kurikulum Tingkat Satuan Pendidikan 2006. Jakarta: Depdiknas. Dimyati, J. (2016). Pembelajaran Terpadu (Untuk Taman Kanakkanak/Raudhatul Athfal dan Sekolah Dasar). Jakarta : Prenadamedia Group.

Ekawati, L. (2010). Pengaruh Pembelajaran Terpadu Model Nested Terhadap Kemampuan Pemecahan Masalah Matematika Siswa Kelas VIII SMP PGRI 1 Ciputat. Jurnal pedagogi, 2, 26-39.

Fathani, A., H., Ilmi, Y., I., N., \& Santriyo, F. (2020). Penerapan Group Investigation Untuk Meningkatkan Kemampuan Pemecahan Masalah Kontekstual Bagi Peserta Didik Kelas X Sma Islam Nusantara Malang Pada Materi Pertidaksamaan Rasional Dan Irrasional. Jurnal Edukasi dan Sains Matematika (JES-MAT), 6(1), pp. 110

Firdaus, E., F. (2019). Pengaruh keaktifan siswa dalam pembelajaran metode probing promting terhadap kemampuan pemecahan masalah matematis materi logika. Jurnal Edukasi dan Sains Matematika (JESMAT), 5(2), pp. 137 - 144.

Huda, A., Isnarto, \& Erwina, L. (2018). Meningkatkan Kemampuan Pembuktian Induktif Kelas XII SMAN 7 Semarang pada Materi Induksi Matematika Melalui Pembelajaran Model TAI. Prosiding Seminar Nasional Matematika (PRISMA), 1, pp. 12-17

Idris, N. (2009). Enhancing students' understanding in calculus trough writing. International Electronic Journal of Mathematics Education, 4(1), pp. 36-55.

Juanti, L, Santoso, B. \& Hiltrimartin, C. (2016). Peningkatan Kemampuan Pemecahan Masalah Siswa Menggunakan Model Pembelajaran Treffinger. Jurnal Pemikiran dan Penelitian Pendidikan. 14(2), pp. 198-217

Kristanto, Y., D. (2013). Induksi Matematika. Dikutip dari: [diakses pada

https://yos3prens.wordpress.com/201 3/10/06/induksi-matematika/]

Kurniawan, D. (2014). Pembelajaran Terpadu Tematik (Teori, Praktik, dan Penilaian). Bandung: Alfabeta.

Kusuma, M., Wahidin, \& Gloria, R., Y. (2015). Penerapan Pembelajaran Terpadu Tipe Nested (Tersarang) Untuk Meningkatkan Literasi Sains Siswa Pada Konsep Ekosistem Di Kelas X Sma Negeri 5 Kota Cirebon. SCIENTIAE EDUCATIA, 5(2).

Maharani, Wahidin, \& Ria. (2015). Penerapan Pembelajaran Terpadu Tipe Nested untuk Meningkatkan Literasi Sains Siswa pada Konsep Ekosistem di Kelas X SMA. .Jurnal Keguruan dan Ilmu Pendidikan. 8, pp. 7-22.

NCTM. (2000). Principles and standars for school mathematics. Roston, VA: National Council of Teacher of mathematics.

Riduwan. (2009). Pengantar Statistika Untuk Penelitian Pendidikan, Sosial, Ekonomi, Komunikasi, dan Bisnis. Bandung: Alfabeta

Sari, D., L. (2019). Pengaruh Model Pembelajaran Terpadu Tipe Nested Terhadap Hasil Belajar Peserta Didik 
Pembelajaran Tematik Kelas V Sd Negeri 1 Pardasuka. Bandar Lampung: Universitas Lampung.

Sumantri, M., S. (2016). Model Pembelajaran Terpadu di Sekolah Dasar. Jakarta: Raja Grafindo Persada.

Suwangsih, E. (2006). Model Pembelajaran Matematika. Bandung: UPI Press.

Trianto. (2017). Model Pembelajaran Terpadu (Konsep, Strategi, dan Implementasinya dalam Kurikulum Tingkat Satuan Pendidikan). Jakarta : Bumi Aksara.

Yuanari, N. (2011). Penerapan Strategi TTW (Think-Talk-Write) Sebagai Upaya Meningkatkan Kemampuan Pemecahan Masalah Dan Disposisi Matematis Siswa Kelas VIII SMP N 5 Wates Kulonprogo. Yogyakarta: Universitas Negeri Yogyakarta 
